\title{
The Potential of Gluten Free Flour Enriched with Resistant Starch Type 3 from Canna Edulis for the Management Profile of Glucose, Lipids and Short Chain Fatty Acid in Healthy Mice
}

\author{
Mutiara Nugraheni, Badraningsih Lastariwati, Sutriyati Purwanti \\ Culinary Art Vocational Education \\ Universitas Negeri Yogyakarta \\ Yogyakarta, Indonesia \\ mutiara_nugraheni@uny.ac.id
}

\begin{abstract}
This research aims to modifying Canna edulis flour to improve resistant starch content and identifying the effect of consumption of gluten-free enriched with resistent starch type 3 from Canna edulis flour toward profil of glucose, lipids and short chain fatty acids in healthy mice. Production of Canna edulis flour rich in resistant starch type 3 with modifications of 3 cycle autoclaving-cooling, and then formulation of the 3 types of glutenfree enriched RS3 from Canna edulis flour. In-vivo analysis was performed using the 24 rats wistar divided into 4 groups: the standard feed, high protein gluten free flour, high fiber gluten-free flour, and all purposes gluten-free flour. Evaluation in vivo done to know the profile of glucose, lipids and short chain fatty acids. The results show that 3 cycle autoclaving-cooling can increase the level of resistant starch at $39.5 \%$. Diet of three types of gluten free can control the profile of glucose and lipids compared to standard feed. The main short chain fatty acids were acetic acid, propionic acid and butyric acid. This indicates that consumption of three types of gluten-free flour enriched RS3 from Canna edulis flour provides positive benefits for profiles of glucose, lipids and short chain fatty acids.
\end{abstract}

Keywords - canna edulis; gluten free; resistant starch tipe 3; glucose; lipids; short chain fatty acid

\section{INTRODUCTION}

Indonesia has great potentials of natural cereals, legumes, or tubers as a source of fat, protein and carbohydrates. However, Indonesia has become a wheat grain importer in the last ten years with imports reaching 10 million tons per year. Some effort needs to be done to produce flour that can be used for a variety of food products as a substitute for wheat. It should be developed based on potential-based raw materials that exist in Indonesia (tubers, grain and legume). One of the efforts is to make gluten free flour based on local potentials, yet containing carbohydrates (starch), fat and protein to support the formation of sensory properties similar to processed wheat-based products.
One of the raw materials used as sources of carbohydrates is Canna edulis.

Canna edulis is a herbaceous plant- which belongs to the group of tubers. Canna edulis tuber is used as a source of food and raw material for industry. In Indonesia, two kinds of Canna edulis cultivars can be found, namely red and white Canna edulis. Canna edulis is a plant that is efficient in the use of nitrogen, drought-tolerant and high-productivity [1].Tubers as a source of carbohydrates can be physically modified to increase the value of functionality i.e. resistant starch type 3 (RS3) content with autoclaving-cooling [2,3]. Several studies proved that the content of resistant starch in foodstuffs is able to control the profile of glucose, and lipids animal or human suffering from diabetes mellitus $[4,5]$. So, it is expected that gluten-free enriched RS3 from Canna edulis flour can create profiles of glucose, lipids and short-chain fatty acid of experimental animals.

Gluten-free flour is a blend of carbohydrates, proteins, fats derived from legumes, cereals and tubers. Based on the raw materials, it can be observed gluten-free flour contains resistant starch and dietary fiber. The presence of a combination of resistant starch type 3 and fiber found in gluten free flour is expected to control glucose and lipids profile in the body. This research aims at modifying the Canna edulis flour with 3 cycle autoclaving-cooling to improve the levels of resistant starch and identify the effect of the consumption of gluten-free enriched RS 3 from Canna edulis flour on the profiles of glucose, lipids and short chain fatty acid in healthy rats.

\section{METHODS}

Canna edulis flour was obtained from farmers in Clereng, Kulon Progo, Yogyakarta, Indonesia. All constituent ingredients 
for the gluten-free flour were obtained from the local market. The glucose kit was purchased from Diagnostic Bavaria Germany Cholesterol kit, triglycerides kit, LDL kit and HDL kit were purchased from Diasys Diagnostic System Holzheim Germany; all reagents were of analytical reagent grade.

Physical modification of Canna edulis and Coleus tuberosus flour was intended to obtain flour with higher levels of resistant starch [6]. There were three types of gluten-free flours produced: high protein gluten free flour, high fiber gluten free flour, and all purposes gluten-free (TABLE I). There were two raw materials that must be present in the formulation of the three types of gluten-free: Canna edulis flour and Canna edulis rich in RS3.

Total starch content [7], amylosa and amylopectin and dietary fiber content [8], and resistant starch [9].

TABLE I. THE COMPOSITION OF THE THREE TYPES OF GLUTEN-FREE FLOUR

\begin{tabular}{|c|c|c|c|c|c|}
\hline \multicolumn{2}{|l|}{ All Purposes } & \multicolumn{2}{|l|}{ High protein } & \multicolumn{2}{|l|}{ High Fiber } \\
\hline Ingredient composition & $\%$ & Ingredient composition & $\%$ & Ingredient composition & $\%$ \\
\hline Rice flour & 51 & Soy flour & 32 & Shorgum flour & 35 \\
\hline Tapioca & 10 & Maize starch & 13 & Maize flour & 19 \\
\hline Canna edulis flour enriched RS3 & 11 & Native Canna edulis flour & 13 & Millet flour & 17 \\
\hline Coleus tuberosus flour enriched RS3 & 1 & Tapioca & 9 & Tapioca & 9 \\
\hline Maize starch & 14 & Canna edulis flour rich in RS3 & 10 & Coleus tuberosus flour rich in RS3 & 1 \\
\hline Native Canna edulis flour & 14 & Coleus tuberosus flour rich in RS3 & 1 & Canna edulis flour rich in RS3 & 9 \\
\hline & & Brown rice flour & 23 & Maize starch & 6 \\
\hline & & & & Native Canna edulis flour & 6 \\
\hline Total & 100 & Total & 100 & Total & 100 \\
\hline
\end{tabular}

Animal diet refers to the standard feed composition of AIN 1993 [10]. Twenty-four male white mice (wistar) weighing 130$180 \mathrm{~g}$ were supplied by the Animal Care laboratory, Gadjah Mada University, Yogyakarta, Indonesia. The rats were kept under control at a temperature of $20-24^{\circ} \mathrm{C}$ and 12 -h light/dark cycle. They were fed with standard feed and water ad-libitum. The gluten-free flour mix and standard feed AIN 93 were used to feed mice for 21 days. Mice were divided into four groups, consisting of six animals respectively. Mice were treated for 21 days as follows: Group 1 received the standard diet, Group 2 received high fiber GFF, Group 3 received high protein GFF, and group 4 received all purposes GFF. Drinking water was provided ad libitum. The blood was collected from retroorbitally anthus in the eye with the ether anesthesia using capillary tubes [11]. The total cholesterol was determined with CHOD-PAP method [12]. LDL-cholesterol was determined with CHOD-PAP method [13]. HDL cholesterol was determined with the CHOD-PAP method. Triglycerides was determined using GPO-PAP method [14]. SCFA was determined with GC.

The results were presented as the average and standard deviation of six experiments. One-way ANOVA was used to analyze differences in means between the samples followed by Least Significant Difference multiple comparison test to compare the mean values at $p<0.05$. The value of $p$ indicates 0.05 which was considered a significant difference $p<0.05$. SPSS version 16.0 (SPSS Inc., South Wacker Drive, Chicago, United State of America) was used.

\section{RESULTS AND DISCUSSIONS}

Resistant starch content of native Canna edulis and 3 cycle autoclaving-cooling are $0.82 \pm 0.01 \%$ and $1.14 \pm 0.01 \%$, repectively. Physical modification process 3 cycle autoclavingcooling can increase the levels of RS 3 of Canna edulis flour about $39.5 \%$. Autoclaving-cooling repeatedly caused the formation of more retrogradated or crystalized amylose fraction, so that it can increase the levels of RS3. The heating process continued with the cooling causing the polymer chain amylose to dissolve because gelatinized will have re-association back form the structure of the double helix stabilized by hydrogen bonds, which result in starch being difficult to be digested by the amylase enzyme, so the impact on the formation of resistant starch. The most resistant starch formed is from amylose, although amylopectin can also be retrogradated but it will take a long time [15].

The levels of RS3 on the three flour types differ markedly (Table 2). The different levels of RS3 on the three type of gluten-free flour are due to the difference of materials constituting. Although these three types of gluten-free flour mix have two raw materials that must be present, namely, native Canna edulis flour, Canna edulis flour rich in RS3 and Coleus tuberosus rich in RS3, other materials that make up the gluten free flour also contain resistant starch. The different types of food will have an impact on the different levels of resistant starch [16]. The levels of resistant starch on these three kinds of gluten-free flour are expected to be further increased when used 
as raw materials for processing various gluten-free based

The ratio of amylose and amylopectin influence the resistant starch content. Canna edulis flour has a higher amylose content, and therefore has higher levels of resistant starch after modification. Each type of starch has different a ratio of amylopectin and amylose. The different characteristics of each type of starch are affected by the botanical source, the shape and size of the starch granules, amylose and amylopectin ratio, the content of the non-starch components, as well as crystalline and amorphous structures [17].

TABLE II shows that the level of amylosa and amylopectin is not directly proportional to the levels of resistant starch, it is supposedly because the starch undergoes modification autoclaving-cooling only two types namely Canna edulis flour and Coleus tuberosus flour, whereas the other ingredients were native flour. Resistant starch type 3 occured with heatingcooling. So, it is possible that the high levels of amylosa on a material are comparable to the high levels of resistant starch in the product.

TABLE II. RESISTANT STARCH (RS), STARCH, AMYLOSE, AMYLOPECTIN AND SOLUBLE DIETARY FIBER (SDF), INSOLUBLE DIETARY FIBER (IDF), TOTAL DIETARY FIBER (TDF) CONTENT OF GLUTEN FREE FLOUR (GFF)

\begin{tabular}{|c|c|c|c|c|c|c|c|}
\hline $\begin{array}{l}\text { Kind of } \\
\text { GFF }\end{array}$ & $\begin{array}{l}\text { RS } \\
(\%)\end{array}$ & $\begin{array}{l}\text { Star } \\
\text { ch } \\
(\%)\end{array}$ & $\begin{array}{l}\text { Amy } \\
\text { lose } \\
(\%)\end{array}$ & $\begin{array}{l}\text { Amylo } \\
\text { pectin } \\
(\%)\end{array}$ & $\begin{array}{l}\text { SDF } \\
(\%)\end{array}$ & $\begin{array}{l}\text { IDF } \\
(\%)\end{array}$ & $\begin{array}{l}\text { TDF } \\
(\%)\end{array}$ \\
\hline $\begin{array}{l}\text { All } \\
\text { purpose } \\
\text { GFF }\end{array}$ & $\begin{array}{l}0.66 \\
\pm 0.0 \\
1^{\mathrm{a}}\end{array}$ & $\begin{array}{l}68.8 \\
8 \pm 0 . \\
14^{b}\end{array}$ & $\begin{array}{l}18.7 \\
8 \pm 0 . \\
07^{\mathrm{C}}\end{array}$ & $\begin{array}{l}50.10 \pm \\
0.21^{\mathrm{b}}\end{array}$ & $\begin{array}{l}0.78 \\
\pm 0.0 \\
1^{\mathrm{b}}\end{array}$ & $\begin{array}{l}5.40 \\
\pm 0.0 \\
87^{\mathrm{b}}\end{array}$ & $\begin{array}{l}6.13 \\
\pm 0.1 \\
4 \mathrm{~b}\end{array}$ \\
\hline $\begin{array}{l}\text { High } \\
\text { fiber } \\
\text { GFF }\end{array}$ & $\begin{array}{l}1.35 \\
\pm \\
0.09^{\mathrm{b}}\end{array}$ & $\begin{array}{l}69.4 \\
6 \pm 0 . \\
15^{\mathrm{c}}\end{array}$ & $\begin{array}{l}10.1 \\
5 \pm 0 . \\
04^{\mathrm{a}}\end{array}$ & $\begin{array}{l}59.32 \pm \\
0.11^{\mathrm{c}}\end{array}$ & $\begin{array}{l}2.32 \\
\pm 0.0 \\
5^{c}\end{array}$ & $\begin{array}{l}14.8 \\
0 \pm 0 . \\
08^{\mathrm{c}}\end{array}$ & $\begin{array}{l}17.1 \\
1 \pm 0 . \\
13^{\mathrm{c}}\end{array}$ \\
\hline $\begin{array}{l}\text { High } \\
\text { protein } \\
\text { GFF }\end{array}$ & $\begin{array}{l}1.40 \\
\pm \\
0,01^{\mathrm{c}}\end{array}$ & $\begin{array}{l}62.3 \\
4 \pm 0 . \\
08^{\mathrm{a}}\end{array}$ & $\begin{array}{l}14.5 \\
9 \pm 0 . \\
04^{\mathrm{b}}\end{array}$ & $\begin{array}{l}47.76 \pm \\
0.05^{\mathrm{a}}\end{array}$ & $\begin{array}{l}0.72 \\
\pm 0.0 \\
4^{\mathrm{a}}\end{array}$ & $\begin{array}{l}4.95 \\
\pm 0.0 \\
1^{\mathrm{a}}\end{array}$ & $\begin{array}{l}5.67 \\
\pm 0.0 \\
5^{\mathrm{a}}\end{array}$ \\
\hline
\end{tabular}

Some researchers have also proved that the levels of amylose is correlated with the formation of resistant starch $[18,19]$.

This study shows that the total dietary fiber of high fiber gluten free flour was higher than the high protein and all purpose gluten free flour (TABLE II). The soluble dietary fiber (SDF) and the insoluble dietary fiber (IDF) also contributed to the increase of the total dietary fiber. Resistant starch will be detected as dietary fiber, insoluble but its physiological function acts as soluble fiber [20]. TABLE III shows the content of dietary fiber on the three types of gluten-free flour. The difference is due to the composition of different gluten-free products enriched RS3 from Canna edulis flour.

flour. High fiber gluten free flour contains the highest total dietary fiber $(17.112 \pm 0.134 \%)$ than all purpose and high protein.

The glucose profiles of the wistar mice with four types of diets were presented in TABLE II. The diet treatment for 21 days with the standard feed and three types of gluten-free enriched RS3 from Canna edulis flour can keep the blood glucose profile of wistar rats under normal conditions $(<135$ $\mathrm{mg} / \mathrm{dL}$ ).

Some types of flour used to make all purpose gluten free enriched with RS3 from Canna edulis flour were able to control blood glucose levels, namely corn flour, Coleus tuberosus rich in RS3, native Canna edulis flour, and Canna edulis rich in RS3. Coleus tuberosus flour rich in RS3 and Canna edulis flour rich in RS3 flour contain RS and fiber related to blood sugar control. Corn contains fiber and has low glycemic index. Dietary fiber corn was $10.46 \%$ [21]. High fiber Gluten free enriched with RS3 from Canna edulis flour has some types of flour that capable of controlling blood glucose profile i.e. sorghum flour, flour milet, corn starch, native Canna edulis flour, Canna edulis flour rich in RS3, Coleus tuberosus rich in RS3. The coarse fiber flour millet Pennisetum glaucum is $6.64 \%$ [22]. High protein gluten free enriched with RS3 from Canna edulis flour also has constituents which are capable to control profiles of glucose i.e., soy flour and rice flour. The protein content of soybean flour was $46.39 \%$. Protein levels can control blood glucose. A high-protein diet may improve blood glucose control in persons with type 2 diabetes [23]. Diet free amino acids and a mixture of proteins can increase insulin secretion reported in type 2 DM patients, it can be control blood glucose [24]. Supplementing the diet with soybean shows a beneficial effect on the improvement of blood glucose control, lipid metabolism and antioxidant enzyme activities in type 2 DM patients [25]. Mechanisms that could explain the influence of fiber consumption toward the decrease in blood glucose level is through the formation of the gel resulting in delays gastric emptying, and ultimately lower the speed of absorption of glucose and plasma insulin levels.

Resistant starches affect postprandial glucose levels through three common mechanisms: inhibiting $\alpha$-amylase from digesting starch into glucose, increasing the viscosity of chyme in the small intestine which slows the rate of glucose uptake, and binding glucose which prevents its diffusion into the mucosal cells, regulated through promoting glycogen synthesis, inhibiting gluconeogenesis, improved glucose tolerance, insulin sensitivity, and satiety have resulted from the consumption of RS in healthy humans [26, 27, 28].

The levels of total cholesterol after 21 days of treatment still showed normal levels $(<130 \mathrm{mg} / \mathrm{dl})$ [29]. When compared to the standard feed, the total cholesterol levels in the three groups of mice with gluten-free flour diet were lower. This suggests that gluten-free flour can control and improve the profile of total cholesterol. The ability of controlling the levels of total 
cholesterol in these three types of gluten-free flour is caused by several factors, namely the presence of resistant starch type 3, fiber, and protein [30]. If compared to the standard feed, glutenfree flour has triglyceride levels which tend to be lower.

TABLE II shows that the diet of the rats with three types of gluten-free flour has a normal HDL levels [29]. Although there is a tendency to decrease compared to the first day, if compared to the standard feed diet, HDL levels in the rats given flour gluten-free diet are better. This proves that flour gluten-free diet on rats improve HDL levels. Animals fed given all purpose gluten free flour, high fiber flour which is gluten-free or high protein flour gluten-free for 21 days show a trend of lower LDL levels than standard feed (TABLE II). LDL levels in rats fed, namely gluten-free flour has been lower $40 \mathrm{mg} / \mathrm{dl}$. This suggests that gluten-free flour could improve LDL levels in rats.

The profile of SCFA in TABLE III indicates that the fermentation of the diet of rats produces three types of shortchain fatty acids namely acetate, propionate and butyrate (TABLE III).

TABLE III. PROFILE OF GLUCOSE AND LIPIDS IN RATS WITH DIET FEED STANDARDS AND GLUTEN FREE (GFF)

\begin{tabular}{|c|c|c|c|c|c|c|c|c|c|c|}
\hline \multirow[t]{2}{*}{ Kind of feed } & \multicolumn{2}{|c|}{ Glucose } & \multicolumn{2}{|c|}{ Cholesterol total } & \multicolumn{2}{|c|}{ Triglycerides } & \multicolumn{2}{|c|}{ LDL } & \multicolumn{2}{|c|}{ HDL } \\
\hline & Day 1 & Day 28 & Day 1 & Day 28 & Day 1 & Day 28 & Day 1 & Day 28 & Day 1 & Day 28 \\
\hline Standard feed & $\begin{array}{l}63.17 \pm \\
2.04^{\mathrm{ab}}\end{array}$ & $\begin{array}{l}98.33 \pm \\
1.86^{\mathrm{e}}\end{array}$ & $\begin{array}{l}89.17 \pm \\
2.23^{\mathrm{a}}\end{array}$ & $\begin{array}{l}116.00 \pm \\
3.16^{\mathrm{d}}\end{array}$ & $\begin{array}{l}77,83 \pm \\
2,04^{\mathrm{b}}\end{array}$ & $\begin{array}{l}105.33 \pm \\
2.81^{\mathrm{e}}\end{array}$ & $\begin{array}{l}32.33 \pm \\
1.37^{\mathrm{ab}}\end{array}$ & $\begin{array}{l}64.83 \pm \\
4.40^{\mathrm{e}}\end{array}$ & $\begin{array}{l}59.00 \pm \\
1.79^{c}\end{array}$ & $\begin{array}{l}46.67 \pm \\
1.75^{\mathrm{a}}\end{array}$ \\
\hline All purpose GFF & $\begin{array}{l}61.50 \pm \\
1.22^{\mathrm{a}}\end{array}$ & $\begin{array}{l}70.00 \pm \\
2.19^{\mathrm{c}}\end{array}$ & $\begin{array}{l}85.83 \pm \\
1.60^{\mathrm{a}}\end{array}$ & $\begin{array}{l}100.00 \pm \\
4.29^{b}\end{array}$ & $\begin{array}{l}66.17 \pm \\
3.31^{\mathrm{a}}\end{array}$ & $\begin{array}{l}87.17 \pm \\
3.87^{\mathrm{c}}\end{array}$ & $\begin{array}{l}32.50 \pm \\
2.59^{\mathrm{ab}}\end{array}$ & $\begin{array}{l}35.50 \pm \\
1.87^{\mathrm{c}}\end{array}$ & $\begin{array}{l}61.00 \pm \\
2.61^{\text {cd }}\end{array}$ & $\begin{array}{l}58.50 \pm \\
2.17^{\mathrm{c}}\end{array}$ \\
\hline High Fiber GFF & $\begin{array}{l}64.50 \pm \\
2.95^{\mathrm{b}}\end{array}$ & $\begin{array}{l}74.67 \pm \\
2.16^{\mathrm{d}}\end{array}$ & $\begin{array}{l}88.67 \pm \\
2.33^{\mathrm{a}}\end{array}$ & $\begin{array}{l}109.17 \pm \\
4.36^{\mathrm{c}}\end{array}$ & $\begin{array}{l}68.67 \pm \\
4.27^{\mathrm{a}}\end{array}$ & $\begin{array}{l}98.33 \pm \\
4.32^{\mathrm{d}}\end{array}$ & $\begin{array}{l}29.83 \pm \\
1.72^{\mathrm{a}}\end{array}$ & $\begin{array}{l}39.17 \pm \\
2.14^{\mathrm{d}}\end{array}$ & $\begin{array}{l}59.17 \pm \\
2.86^{\mathrm{c}}\end{array}$ & $\begin{array}{l}53.67 \pm \\
2.80^{\mathrm{b}}\end{array}$ \\
\hline High Protein GFF & $\begin{array}{l}64.83 \pm \\
2.93^{\mathrm{b}}\end{array}$ & $\begin{array}{l}65.83 \pm \\
2.79^{\mathrm{b}}\end{array}$ & $\begin{array}{l}86.83 \pm \\
4.22^{\mathrm{a}}\end{array}$ & $\begin{array}{l}87.50 \pm \\
4.23^{\mathrm{a}}\end{array}$ & $\begin{array}{l}74.67 \pm \\
5.75^{\mathrm{b}}\end{array}$ & $\begin{array}{l}75.67 \pm \\
5.40^{\mathrm{b}}\end{array}$ & $\begin{array}{l}31.00 \pm \\
2.10^{\mathrm{ab}}\end{array}$ & $\begin{array}{l}33.33 \pm \\
1.75^{\mathrm{bc}}\end{array}$ & $\begin{array}{l}63.67 \pm \\
4.63^{d}\end{array}$ & $\begin{array}{l}63.00 \pm \\
4.60^{\mathrm{d}}\end{array}$ \\
\hline
\end{tabular}

TABLE IV. PROFIL OF SHORT CHAIN FATTY ACID RATS WITH DIET FEET STANDARD AND GLUTEN FREE FLOUR (GFF)

\begin{tabular}{|l|l|l|l|l|}
\hline \multicolumn{1}{|c|}{ Type of diet } & \multicolumn{1}{|c|}{ Acetate } & \multicolumn{1}{c|}{ Propionate } & Botyrate SCFA \\
\hline Standard & $41.28 \pm 2.61^{\mathrm{ab}}$ & $37.54 \pm 1.71^{\mathrm{d}}$ & $10.14 \pm 0,44^{\mathrm{d}}$ & $88.96 \pm 4,68^{\mathrm{c}}$ \\
All purpose GFF & $27.85 \pm 0.55^{\mathrm{a}}$ & $13.99 \pm 0.43^{\mathrm{a}}$ & $4.90 \pm 0.44^{\mathrm{a}}$ & $46.75 \pm 0.51^{\mathrm{a}}$ \\
High fiber GFF & $42.74 \pm 9.21^{\mathrm{b}}$ & $30.78 \pm 2.18^{\mathrm{c}}$ & $8.01 \pm 0,29^{\mathrm{c}}$ & $81.53 \pm 10.64^{\mathrm{bc}}$ \\
High protein GFF & $36.39 \pm 9.86^{\mathrm{ab}}$ & $25.63 \pm 2.72^{\mathrm{b}}$ & $6.74 \pm 0.26^{\mathrm{b}}$ & $68.75 \pm 12,32^{\mathrm{b}}$ \\
\hline
\end{tabular}

The major SCFA produced in the human intestine is acetate, propionate, and butyrate. Short-chain fatty acids have health benefits for the body and metabolism of glucose and fat. Acetate is metabolized in the liver, muscle, brain tissue. Propionate metabolized in the liver as well as being able to lower their cholesterol synthesis. Butyrate shows the ability to inhibit the growth of colorectal cancer by way of inhibiting the proliferation of cells, as well as improve the ability of differentiation and apoptosis of cells [31].

Decrease in the profile of total cholesterol, triglycerides and LDL related to short-chain fatty acids is produced from the fermentation of resistant starch and dietary fiber. SCFA is the result of fermentation of dietary fiber in the colon such as acetate, propionate and butyrate [32]. Propionate is produced from the fermentation of fiber on colon will inhibit the synthesis of cholesterol Propionate after entering the bloodstream and liver can inhibit the action of the enzyme HMG-CoA reductase and reduce cholesterol synthesis.

\section{CONCLUSION}

Treatment with 3 cycle autoclaving cooling can increase the content of resistant starch in the Canna edulis flour at 39.5\%. The formulation of three types of gluten-free enriched RS3 from Canna edulis flour provides the content of different chemical compositions, which depend on ingredients constituting. Three types of fluten free flour enriched RS3 from Canna edulis flour give a positive influence and able to control the profile of glucose, lipids and short chain fatty acids. Gluten free flour 
enriched RS3 from Canna edulis flour can potentially be used as functional food for people who are allergic to gluten or people who require the control of glucose and lipids profile.

\section{ACKNOWLEDGMENT}

The author would like to thank the Directorate General of Higher Education of the Republic of Indonesia which has funded this research

\section{REFERENCES}

[1] H. Hermann, R. Uptmoor, I. Freire and J. Montalvo, "Crop Growth and Starch Productivity of Edible Canna", Program 6 Postharvest, Management, Marketing. Program Report International Potato Centre (CIP) Lima, Perú (1993).

[2] S. M. Kingman and H. N. Englyst, "The influence of food preparation methods on the in-vitro digestibility of starch in potatoes", Food Chemistry 49(2) (1994) 181-186.

[3] A. N. Dundar and D. Gocmaen, "Effects of autoclaving temperature and storing time on resistant starch forrmation Postharvest, Management, Marketing. Program Report International Potato Centre (CIP) Lima, Perú (1993).

[4] Kay, "Resistant Starch and Soluble Fiber May Improve Glucose Metabolism", Diabetes Care 29 (2006) 976-981.

[5] Y. Yamada, S. Hosoya, S. Nishimira, T. Tanaka, Y. Kajimoto and O. Kejimoto, "Effect of bread containing resistant starch on Postprandial blood glucose levels in human", Bioscience Biotechnology Biochemistry, 69(3) (2005) 559-566.

[6] M. Nugraheni, B. Lastariwati and S. Purwanti, "Proximate and Chemical Analysis of Gluten-free Enriched, Resistant Starch Type 3 from Maranta arundinacea Flour and its Potential as a Functional Food", Pak. J. Nutr. 16 (5) (2017) 322-330,

[7] Association of official Analysis chemist, "Official Methods of Analysis of the AOAC". Gaithersburg. United States: AOAC International (1984)

[8] Association of official analytical chemist, "Official methods of analysis of the association analytical chemists". Washington, DC: AOAC (1995).

[9] H. N. Englyst, S. M. Kingman and J. H. Cummings, "Classification and measurement of nutritionally important starch fraction", European Journal of Clinical Nutrition 46 (1992) 3-50.

[10] P. G. Reeves, "Components of the AIN-93 diets as improvements in the AIN-76A diet", Journal of Nutrition 127(5) (1997) 838S-841S.

[11] J. Hoff, "Technique methods of blood collection in the mouse", International Journal of Laboratory Animals 29(10) (2000) 47-53.

[12] W. Richmond, "Enzymatic determination of total serum cholesterol", Journal of Clinical Chemistry 9 (1973) 1350-1354

[13] H. Wieland and D. Siedal, "Cholesteol determination", Journal of Lipid 24 (1983) 904-905

[14] M. W. McGowan, J. D. Artiss, D. R. Standberg and B. Zaka, "A peroxidecoupled method for the colorimetric determination of serum triglycerides", Journal of Clinical Chemistry 29(3) (1983) 538-542.

[15] D. P. Huang and L. W. Rooney, "Starches for Snacks Foods". In Lusas, R. W. and Rooney, L. W. (eds). Snack Foods Processing (CRC Press. New York, 2001).

[16] M. G. Sajilata, R.S. Singhal and P. R. Kulkarni, "Resistant Starch: A Review, Comprehensive Reviews in Food Science and Food Safety" Vol 5 (2006) 1-17.

[17] S. Mali, L. S. Sakanaka, F. Yamashita and M. V. E. Grossmann, "Water sorption and mechanical properties of cassava starch films and their relation to plasticizing effect", Carbohydrate Polymers 60 (2005) 283-289.

[18] E. Hallstrom, F. Sestili, D. Lafiandra, I. Bjorck and E. Ostman, "A novel wheat variety with elevated content of amylose increases resistant starch formation and may beneficially influence glycaemia in healthy subjects", Food and Nutrition Research 55 (2011) 7074-7082.

[19] F. Sestili, M. Janni, A. Doherty, E. Botticella, R. D’Ovidio, S. Masci, H. D. Jones and D. Lafiandra, "Increasing the amylose content of durum wheat through silencing of SBElla genes", BMC Plant Biology 10 (2010) 1-12.
[20] S. G. Haralampu, "Resistant starch : a review of the physical properties and biological impact of RS3", Carbohydrate Polymers 41 (2000) 285-292.

[21] M. M. V. Naves, M. V. L. Castro, A. L. Mendonca, G. G. Santo and M. S. Silva, "Corn germ with pericarp in relation to whole corn: nutrient contents, food and protein efficiency, and protein digestibility-corrected amino acid score", Ciência e Tecnologia de Alimentos 31(1) (2011) 264269.

[22] R. Souilah, B. Belhadi N. Boudries, D. Djabali and B. Nadjemi, "Pretreatments Effect of Sorghum (Bicolor (L.)Moench) and Millet (Pennisetum Glaucum) Flours on the In Vitro Starch Digestibility", Journal of the University of Chemical Technology and Metallurgy 47(1) (2012) 63 68.

[23] M. G. Gannon, F. Q. Nuttall, A. Saeed, K. Jordan and H. Hoover, 2003. "An increase in dietary protein improves the blood glucose response in persons with type 2 diabetes", American Journal of Clinical Nutrition 78 (2003)734-741.

[24] L. J. C. Van Loon, M. Kruijshoop, P. P. C. A. Menheere, A. J. M. Wagenmakers, H. M. S. Wim and A. K. Hans, "Amino acid ingestion strongly enhances insulin secretion in patiens with long-term type 2 Diabetes", Diabetes care 26 (3) (2003) 625-630.

[25] J. H. Chang, M.S. Kim, T. W. Kim and S. S. Lee, "Effects of soybean supplementation on blood glucose, plasma lipid levels, and erythrocyte antioxidant enzyme activity in type 2 diabetes mellitus patients", Nutrition Research and Practice 2(3) (2008) 152-157

[26] S. Y. Ou, K. C. Kwok, Y. Li and L. Fu, "In vitro study of possible role of dietary fiber in lowering postprandial serum glucose", Journal of Agricultural and Food Chemistry 49(2) (2001)1026-9.

[27] Z. K. Zhou, F. Wang, X. C. Ren, Y. Wang and C. Blanchard, "Resistant starch manipulated hyperglycemia/hyperlipidemia and related genes expression in diabetic rats", Internasional Journal of Biological Macromolecules 75 (2015) 316 -321.

[28] M. M. Murphy, D. J. Spungen and A. Birkett, "Resistant starch intakes in the United States", Journal of the American Dietetic Association 108 (2008) 67-78.

[29] K. W. Jae, "Cholesterol. Indonesian Heart Foundation", available from: URL: URL:http://www.heartinfo.org. 17 September 2008

[30] M. Kristensen, M. G. Jensen, J. Aarestrup, K. E. N. Petersen, L. Søndergaard, M. S. Mikkelsen and A. Astrup, "Flaxseed dietary fibers lower cholesterol and increase fecal fat excretion, but magnitude of effect depend on food type", Nutrition and Metabolism 9(1) (2012) 8.

[31] G. Besten, K. V. Eunen, A. K. Groen, K. Venema, D. J. Reijnqoud and B. M. Bakker, "The role of short-chain fatty acids in the interplay between diet, gut microbiota, and host energy metabolism", Journal of Lipid Research 54(9) (2013) 2325-2340

[32] B. Fotschki, A. Jurgoński, J. Juśkiewicz, K. Kołodziejczyk and M. Sójka, "Effects of Dietary Addition of a Low Pectin Apple Fibre Preparation on Rats”, SPolish Journal of Food Nutrition Sciences 64( 3) (2014) 193-199 